\title{
Myopathy with anti-Jo-1 antibodies: pathology in perimysium and neighbouring muscle fibres
}

\author{
Tahseen Mozaffar, Alan Pestronk
}

\begin{abstract}
Objective-To evaluate muscle pathology and clinical characteristics in patients with a myopathy and serum antibodies to the Jo-1 antigen (histidyl t-RNA synthetase). Background-Anti-Jo-1 antibodies occur in syndromes that may include muscle weakness and pain, Raynaud's phenomenon, interstitial lung disease, arthritis, and a skin rash different from that seen in dermatomyositis. The muscle pathology is not well defined.
\end{abstract}

Methods-Case series. Review of charts, muscle biopsies, and laboratory records. Features of myopathology in 11 patients with anti-Jo-1 antibody associated myopathies were compared with other types of inflammatory myopathies.

Results-Myopathology in patients with anti-Jo-1 antibodies consistently included fragmentation of, and macrophage predominant inflammation in, perimysial connective tissue. Perifascicular myopathic changes, including atrophy, regenerating muscle fibres, and some muscle fibre necrosis, were most common in regions near the connective tissue pathology and were most prominent in patients with more severe weakness. Unlike many other inflammatory myopathies, inflammation in endomysial and perivascular regions was uncommon. By contrast with dermatomyositis, capillary density was normal.

Conclusions-Myopathological changes in the anti-Jo-1 antibody syndrome include perimysial connective tissue fragmentation and inflammation, with muscle fibre pathology in neighbouring perifascicular regions. Myositis with anti-Jo-1 antibodies may result from an immune mediated disorder of connective tissue.

(F Neurol Neurosurg Psychiatry 2000;68:472-478)

Department of Neurology, Washington University School of Medicine, St Louis, MO 63110, USA

T Mozaffar

A Pestronk

Correspondence to:

Dr Alan Pestronk,

Department of Neurology,

Box 8111, 660 South Euclid

Avenue, St Louis, MO

63110, USA

email

pestronk@kids.wustl.edu

Received 22 July 1999 and in revised form

1 November 1999

Accepted 23 November 1999
Keywords: myositis; fasciitis; Jo-1 antibody; myopathy; immune

Serum antibodies that bind to amino-acyl-tRNA synthetases have been identified in the serum of $25 \%$ to $40 \%$ of adults with inflammatory myopathies. ${ }^{12}$ The first to be discovered, and the commonest (15\% to $30 \%$ of adults with polymyositis or dermatomyositis) of these antibodies, anti-Jo-1, is directed against histidyl t-RNA synthetase. ${ }^{3}$ At least four other antisynthetase antibodies have been described. ${ }^{2}$ The antisynthetase antibodies have specificity for clinically distinctive neuromuscular and systemic syndromes that include muscle weakness and pain, Raynaud's phenomenon, interstitial lung disease, arthritis, and skin disorders. ${ }^{4}$ Some patients present with isolated features, such as myositis or interstitial lung disease alone. ${ }^{5}$

Despite numerous clinical studies of antisynthetase antibody associated syndromes, there is little information regarding features of the muscle histopathology in these patients. We evaluated the clinical characteristics and pathological features of muscle in 11 patients who were found to be anti-Jo-1 antibody positive during evaluation of their myopathy. We compared the myopathological changes with those found in other acquired inflammatory myopathies.

\section{Patients and methods}

\section{CLINICAL DATA}

Logs and computerised records from BarnesJewish Hospital in St Louis, Missouri were searched for patients with serum anti-Jo-1 antibodies during the period 1993 to the end of May 1998. Of the 16 patients with anti-Jo-1 antibodies, muscle biopsies were available in 11 from the neuromuscular pathology laboratory at Washington University School of Medicine. All biopsies were obtained before the start of treatment. Clinical data in the 11 patients (table 1) were obtained by chart review. All 11 patients had proximal weakness, progressive over a period of less than a year, muscle pain, and myopathic changes with inflammation on muscle biopsy. Most had an increased serum creatine kinase. For comparison, we also evaluated 37 consecutive biopsies that were examined in our pathology laboratory between 1993 and March 1997, with pathological diagnoses of active inflammatory myopathy (dermatomyositis $(n=18)$ and polymyositis $(n=19))$, other than inclusion body myositis (table 2; pathology series). We also evaluated muscle pathology in eight patients with inclusion body myositis and five patients with fasciitis, who were evaluated in the Washington University Neuromuscular Clinic. In these groups the diagnosis was based on both clinical and pathological features. The patients with inclusion body myositis were evaluated and diagnosed between 1993 and 1997. They all had characteristic clinical, laboratory, and pathological features of the disease, including an inflammatory myopathy characterised by mononuclear invasion of non-necrotic muscle fibres and vacuolated (rimmed) fibres. ${ }^{6}$ Vacuoles were associated with amyloid deposits identified by Congo red stain in four of the eight biopsies $(50 \%)$. Patients with fasciitis had diagnoses of eosinophilia myalgia (two), fasciitis in the setting of a systemic connective tissue disease (two), and eosinophilic fasciitis (one). Two control groups of consecutive patients evaluated in our clinic were obtained after the 


\begin{tabular}{|c|c|c|c|c|c|c|c|c|c|c|c|}
\hline & \multicolumn{11}{|c|}{ Patient No } \\
\hline & 1 & 2 & 3 & 4 & 5 & 6 & 7 & 8 & 9 & 10 & 11 \\
\hline \multicolumn{12}{|l|}{ Clinical features: } \\
\hline Onset age (y) & 23 & 63 & 18 & 36 & 42 & 42 & 54 & 56 & 55 & 58 & 61 \\
\hline Sex & $\mathrm{F}$ & $\mathrm{F}$ & $\mathrm{F}$ & $\mathrm{M}$ & $\mathrm{F}$ & $\mathrm{F}$ & $\mathrm{F}$ & $\mathrm{F}$ & $\mathrm{F}$ & $\mathrm{F}$ & $\mathrm{F}$ \\
\hline Proximal weakness & ++ & ++ & + & ++ & + & + & + & + & + & + & ++ \\
\hline Muscle pain & + & + & + & + & + & + & + & + & + & + & + \\
\hline Dyspnoea and cough & + & + & + & - & - & - & - & - & - & - & - \\
\hline Arthritis & + & + & + & + & + & + & & - & + & - & - \\
\hline Skin rash & + & - & - & - & + & + & - & - & - & - & - \\
\hline Mechanic's hands & - & - & - & + & + & + & - & - & - & - & - \\
\hline Raynaud's phenomenon & - & - & + & - & + & - & - & - & - & - & - \\
\hline Steroid response & + & + & + & + & & + & + & + & + & + & \\
\hline \multicolumn{12}{|l|}{ Laboratory data: } \\
\hline Creatine kinase (IU/1) & 35000 & 10000 & 500 & 4700 & 2100 & 390 & 1500 & 230 & 1600 & 110 & 1000 \\
\hline Packed cell volume & 32 & & 31 & WNL & WNL & WNL & 34 & 42 & 36 & 34 & \\
\hline Erythrocyte sedimentation rate $(\mathrm{mm} / \mathrm{h})$ & 132 & & 72 & 31 & 6 & 25 & 60 & 42 & 60 & 42 & \\
\hline Antinuclear antibody & $1: 5120$ & - & & - & - & - & - & - & $1: 40$ & $1: 80$ & \\
\hline \multicolumn{12}{|l|}{ Muscle pathology: } \\
\hline \multicolumn{12}{|l|}{ Inflammation: } \\
\hline Perimysial & ++ & +++ & ++ & + & ++ & ++ & ++ & ++ & ++ & ++ & + \\
\hline Endomysial & - & ++ & ++ & - & - & - & - & - & - & - & - \\
\hline Perivascular & - & - & - & + & - & - & - & - & - & - & - \\
\hline \multicolumn{12}{|l|}{ Perifascicular muscle fibre } \\
\hline pathology & +++ & $+++/$ Diffuse & ++ & + & Patchy & ++ & ++ & ++ & + & + & + \\
\hline $\begin{array}{l}\text { Perimysial connective tissue } \\
\text { fragmentation }\end{array}$ & & & & & & & & & & & \\
\hline $\begin{array}{l}\text { fragmentation } \\
\text { Acid phosphatase: perimysial }\end{array}$ & ++ & + & + & + & + & ++ & ++ & +++ & + & + & + \\
\hline $\begin{array}{l}\text { Actaining } \\
\text { stainate. perminysial }\end{array}$ & ++ & + & + & + & ++ & ++ & ++ & ++ & + & + & + \\
\hline Alkaline phosphatase: perimysial & & & & & & & & & & & \\
\hline staining & +++ & ++ & ++ & + & ++ & - & + & + & + & + & ++ \\
\hline $\begin{array}{l}\text { Alkaline phosphatase: small vessel } \\
\text { staining }\end{array}$ & - & _- & - & - & - & + & - & - & - & _- & - \\
\hline Cytochrome oxidase negative muscle fibres & - & - & - & - & - & - & - & - & - & + & - \\
\hline
\end{tabular}

Weakness: $++=$ Moderate to severe (MRC grade strength $\leqslant 3$ in some muscles); $+=$ Mild (MRC grade strength $\geqslant 4$ in all muscles).

Other features: $+=$ present; $++=$ moderately increased; $+++=$ markedly increased; $-=$ negative/absent; $\pm=$ equivocal; $F=$ female; $M=$ male.

initial analysis of anti-Jo-1 antibody associated biopsies (table 2; clinical+pathology series). Testing for anti-Jo-1 antibodies was performed in 11 patients who were diagnosed, based on both clinical and pathological features, with definite polymyositis. ${ }^{7}$ Three patients (Nos 9-11) had positive tests for anti-Jo-1 antibodies (table 1). Of the eight patients with polymyositis and negative testing for antibodies to Jo-1, four had associated systemic disorders (connective tissue disease (three); breast cancer (one)), and two had an excess of cytochrome oxidase negative muscle fibres on muscle biopsy. A second control group consisted of eight consecutive patients with a clinical and pathological diagnosis of definite dermatomyositis biopsies (table 2; clinical+pathology series). ${ }^{7}$ Anti-Jo-1 antibodies were negative in the seven patients in this group for whom serum testing was performed.

LABORATORY DATA

Cryostat sections of rapidly frozen muscle were processed in a standard fashion. ${ }^{89}$ The muscle

Table 2 Anti-fo-1 versus other inflammatory myopathies:comparative pathology data

\begin{tabular}{|c|c|c|c|c|c|c|c|c|c|c|c|c|c|c|}
\hline & & & \multicolumn{4}{|c|}{ Dermatomyositis } & \multirow{2}{*}{\multicolumn{2}{|c|}{$\begin{array}{l}\text { Polymyositis } \\
\text { pathology } \\
\text { series }\end{array}$}} & \multirow{2}{*}{\multicolumn{2}{|c|}{$\begin{array}{l}\text { fo-1 negative } \\
\text { polymyositis } \\
\text { clinical }+ \text { path }\end{array}$}} & \multirow{2}{*}{\multicolumn{2}{|c|}{$\begin{array}{l}\text { IBM clinical } \\
+ \text { path }\end{array}$}} & \multirow{2}{*}{\multicolumn{2}{|c|}{$\begin{array}{l}\text { Fasciitis clinical + } \\
\text { path }\end{array}$}} \\
\hline & \multicolumn{2}{|c|}{$\begin{array}{l}\text { Anti-fo-1 } \\
\text { myositis }\end{array}$} & \multicolumn{2}{|c|}{$\begin{array}{l}\text { Pathology } \\
\text { series }\end{array}$} & \multicolumn{2}{|c|}{$\begin{array}{l}\text { Clinical + } \\
\text { path series }\end{array}$} & & & & & & & & \\
\hline & $n+$ & $\%+$ & $n+$ & $\%+$ & $n+$ & $\%+$ & $n+$ & $\%+$ & $n+$ & $\%+$ & $n+$ & $\%+$ & $n+$ & $\%+$ \\
\hline Biopsies (n) & \multicolumn{2}{|l|}{11} & \multicolumn{2}{|l|}{18} & \multicolumn{2}{|l|}{8} & \multicolumn{2}{|l|}{19} & \multicolumn{2}{|l|}{8} & \multirow{2}{*}{\multicolumn{2}{|c|}{8}} & \multirow{2}{*}{\multicolumn{2}{|c|}{5}} \\
\hline \multicolumn{11}{|l|}{ Perifascicular myopathy } & & & & \\
\hline Atrophic muscle fibres & 11 & 100 & 18 & 100 & 8 & 100 & 0 & $0 \dagger$ & 0 & $0 \dagger$ & 0 & $0 \dagger$ & 1 & $20^{\star \star \star \star}$ \\
\hline Myopathic changesł & 10 & 91 & 12 & 67 & 6 & 75 & 0 & $0+$ & 0 & $0 \dagger$ & 0 & $0+$ & 1 & $20^{\star \star}$ \\
\hline \multicolumn{15}{|l|}{ Inflammation (focal) } \\
\hline Perimysial & 11 & 100 & 7 & $39 \dagger$ & 1 & 13 & 3 & $16 \dagger$ & 3 & $38^{\star \star \star}$ & 0 & $0+$ & 5 & 100 \\
\hline Endomysial & 2 & 18 & 4 & 22 & 3 & 37 & 15 & $79+$ & 4 & 50 & 8 & $100 t$ & 0 & 0 \\
\hline Perivascular & 1 & 9 & 12 & $67^{\star \star}$ & 4 & 50 & 13 & $68^{\star \star \star \star}$ & 5 & $63^{\star}$ & 4 & 50 & 2 & 40 \\
\hline $\begin{array}{l}\text { Perimysial connective tissue } \\
\text { fragmentation }\end{array}$ & 11 & 100 & 3 & $17 \dagger$ & 0 & 0 & 3 & $16+$ & 1 & $11 \dagger$ & 0 & 0 & 3 & 60 \\
\hline \multicolumn{15}{|l|}{ Alkaline phosphatase } \\
\hline Perimysial staining & 10 & 91 & 10 & 56 & 2 & 25 & 8 & $42^{\star \star}$ & 3 & $38^{\star}$ & 3 & 38 & 1 & $20^{\star \star}$ \\
\hline Small vessel staining & 1 & 9 & 10 & 56 & 5 & 63 & 4 & $21^{\star}$ & 2 & 25 & 4 & 50 & 1 & 20 \\
\hline \multicolumn{15}{|l|}{ COX- muscle fibres } \\
\hline Perifascicular & 0 & 0 & 11 & $61^{\star}$ & 5 & 63 & 0 & 0 & 0 & 0 & 0 & 0 & 0 & 0 \\
\hline Scattered $(>3 \%)$ & 0 & 0 & 0 & 0 & 0 & 0 & 7 & $37^{\star}$ & 2 & 25 & $5^{\dagger}$ & 63 & 0 & 0 \\
\hline Capillary index $\llbracket$ & \multicolumn{2}{|c|}{$0.88(0.16)$} & & & \multicolumn{2}{|c|}{$0.55(0.08)^{\star}$} & & & \multicolumn{2}{|c|}{$0.95(0.10)$} & & & \multicolumn{2}{|c|}{$0.88(0.13)$} \\
\hline
\end{tabular}

$\mathrm{n}+=$ Number positive; $\%+=$ per cent positive; pathological (path) series: pathological changes consistent with diagnosis.

Clinical+path series: definite diagnosis by clinical, laboratory, and pathological criteria. ${ }^{7}$

Different from Anti-Jo-1 myositis: ${ }^{\star} \mathrm{p} \leqslant 0.05 ;{ }^{\star \star} \mathrm{p}<0.02{ }^{\star \star \star} ; \mathrm{p} \leqslant 0.01 ;+\mathrm{p} \leqslant 0.001$

$\ddagger$ Myopathic changes: muscle fibre necrosis or regeneration

\Capillary index (mean (SE)): Capillaries $/ 1000 \mu \mathrm{m}^{2}$ muscle fibre area; normal $=0.85(0.02)$.

COX-=cytochrome oxidase negative. 
Table 3 Pathology in disorders with inflammation in muscle: comparative patterns

\begin{tabular}{|c|c|c|c|c|c|c|}
\hline & Focal inflammation & $\begin{array}{l}\text { Perimysial } \\
\text { connective } \\
\text { tissue } \\
\text { fragmentation }\end{array}$ & Myopathic changes & $\begin{array}{l}\text { Capillary } \\
\text { pathology }\end{array}$ & Alkaline phosphatase stain & COX- muscle fibres \\
\hline Myositis + anti-Jo- 1 antibodies & $\begin{array}{l}\text { Perimysial } \\
\text { connective tissue }\end{array}$ & Present & Perifascicular & None & Perimysial connective tissue & Infrequent \\
\hline Dermatomyositis & Perivascular & Uncommon & Perifascicular & $\begin{array}{l}\text { Yes } \\
\text { Number } \downarrow\end{array}$ & Small vessel & Perifascicular \\
\hline Polymyositis & $\begin{array}{l}\text { Endomysial } \\
\text { Perivascular }\end{array}$ & Uncommon & $\begin{array}{l}\text { Diffuse } \pm \text { focal invasion } \\
\text { of muscle fibres }\end{array}$ & None & $\begin{array}{l} \pm \text { Perimysial connective } \\
\text { tissue }\end{array}$ & $\begin{array}{l}\text { None, or scattered } \\
\text { endomysial }\end{array}$ \\
\hline Inclusion body myositis & $\begin{array}{l}\text { Endomysial } \\
\text { Perivascular }\end{array}$ & None & $\begin{array}{l}\text { Diffuse: focal invasion } \\
\text { of fibres }\end{array}$ & None & \pm Small vessel & $\begin{array}{l}\text { Scattered } \\
\text { endomysial }\end{array}$ \\
\hline Fasciitis & $\begin{array}{l}\text { Perimysial } \\
\text { connective tissue }\end{array}$ & Present & None & None & None & None \\
\hline
\end{tabular}

pathologist (AP) was blinded to the status of anti-Jo- 1 antibodies in the serum at the time of biopsy interpretation. Immunocytochemistry was performed in the 11 biopsies from patients with anti-Jo-1 antibodies using standard protocols for CD68, CD3, and C5b-9 (membrane attack complex (MAC)) antigens, and for Ulex europaeus agglutinin I (UEA-I) (Sigma; St Louis, MO, USA) binding to capillaries using peroxidase conjugated secondary antibodies (Sigma; St Louis, MO, USA). ${ }^{10} 11$

Assays for anti-Jo-1 antibodies were usually performed by the Oklahoma Medical Research Foundation (Oklahoma City, OK, USA) using immunoprecipitation methodology. ${ }^{12}$ Three serum samples were tested at Mayo Clinical Laboratories (Rochester, MN, USA).

DATA ANALYSIS

Light microscope images from regions chosen for quantitative analysis were stored digitally (Pax-it!, Midwest Information Systems), and evaluated manually. The abundance of capillaries was evaluated by measurements of the number of capillaries $/ 1000 \mu \mathrm{m}^{2}$ of muscle fibre area (capillary index). ${ }^{11}$ Fisher's exact and Mann-Whitney rank sum tests were used to calculate the statistical significance of differences between groups.

\section{Results}

CLINICAL CHARACTERISTICS OF PATIENTS WITH ANTI-JO-1 ANTIBODIES (TABLE 1)

The ages of onset of weakness in the 11 patients with serum anti-Jo-1 antibodies ranged from 18 to 63 years with a mean of 46 years. Ten were women. All had a history of pain, stiffness, and proximal weakness. Dyspnoea and chronic cough were noted by three patients. On examination all patients had proximal, symmetric weakness involving upper and lower limbs. Weakness was relatively severe (MRC grades of 3 or less in some muscles) in four patients $(1,2,4$, and 11). Skin abnormalities (skin rash or mechanic's hands) and Raynaud's phenomenon were found in three patients each. On laboratory testing four patients had a mild anaemia. None had eosinophilia. Serum creatine kinase was increased in nine of 11 patients, ranging from 110 to $35000 \mathrm{IU} / 1$. Only one patient had an antinuclear antibody (ANA) greater than 1:80 (patient $1 ; 1: 5120$ ). Electromyography in all nine patients tested showed an irritable myopathy (small amplitude, brief action potentials, and increased insertional activity, such as fibrillation potentials and positive sharp waves). Pulmonary function testing showed restrictive disease in two of the three patients tested. The nine patients who were treated with prednisone had symptomatic benefit. In two patients the disease relapsed after tapering of the steroid. Two patients died during the study period, one of intracerebral haemorrhage after antithrombotic therapy, and the other from pulmonary disease.

MUSCLE PATHOLOGY IN PATIENTS WITH ANTI-JO-1 ANTIBODIES (TABLES 1-3, FIGS 1-4)

Muscle biopsies from all 11 patients with antiJo-1 antibodies contained regions of fragmented, rarefied perimysial connective tissue (fig 1). Inflammatory cells were predominantly located in the perimysial connective tissue (fig 2 ), especially the fragmented regions. Inflammation was less common in endomysial (two of $11 ; 18 \% ; \mathrm{p}=0.003$ ) and perivascular (one of $11 ; 9 \% ; \mathrm{p}<0.001)$ regions of muscle. Many perimysial inflammatory cells were prominently stained by markers for histiocytes (acid phosphatase and esterase), and macrophages (CD68) (figs 1 and 2). Rare focal cellular accumulations in the perimysium were a mixed population, containing lymphocytes and some macrophages, but few eosinophils.

Muscle fibre atrophy, regeneration (basophilic staining with haematoxylin and eosin, or intermediate colour on ATPase, $\mathrm{pH} 4.3$ ), and some necrosis (diffuse pale staining and a hyaline appearance on haematoxylin and eosin), occurred in perifascicular regions in most biopsies (fig 3), but could also be seen more diffusely. In two patients $18 \%$ and $22 \%$ of muscle fibres in the biopsy were necrotic. Diffuse staining of regions of perimysial connective tissue for alkaline phosphatase (fig $1 \mathrm{E}$ ) was common (10 of $11 ; 91 \%)$, but staining of small vessels was not (one of $11 ; 9 \%$ ). Muscle fibres lacking cytochrome oxidase staining were only present in one patient. Focal cellular invasion of intact muscle fibres was uncommon in antiJo-1 antibody-associated myositis (two of 11 ; $18 \%$ ). The mean capillary index, 0.88 (SD 0.16 ), in anti-Jo-1 antibody associated myositis was similar to control muscle, 0.85 (SD 0.02) (table 2, fig 4).

PATHOLOGY IN OTHER ACQUIRED INFLAMMATORY DISORDERS

In both dermatomyositis and polymyositis patients the pathological changes were similar in the pathology series and in the prospective 

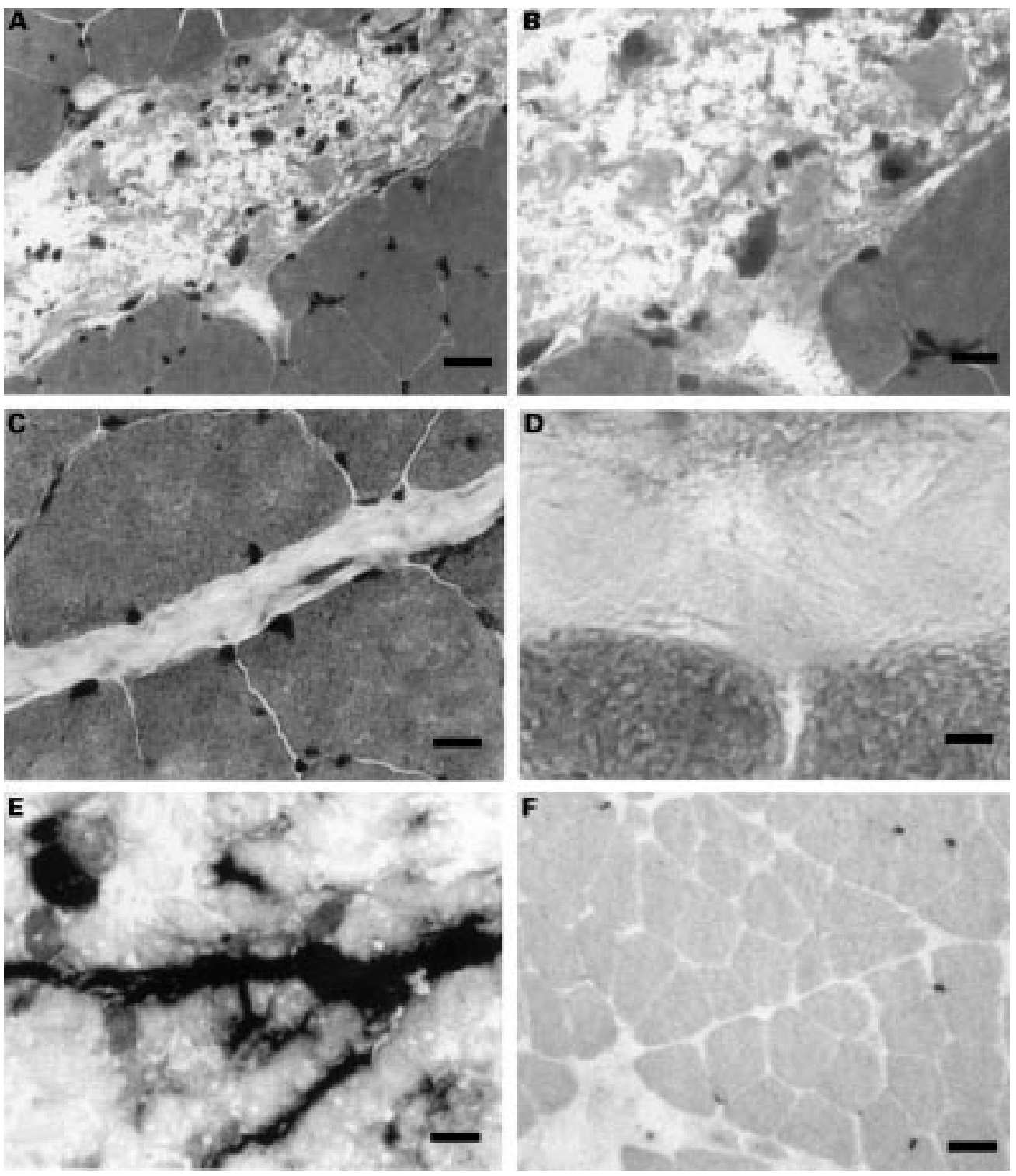

Figure 1 Perimysial pathology. (A) Rarefied and fragmented perimysial connective tissue containing inflammatory cells with prominent cytoplasm. Most cells are probably macrophages (haemotoxylin and eosin stain; $\times 200 ;$ bar $=32 \mu \mathrm{m}$ ). (B) High power view of rarefied and fragmented perimysial connective tissue containing inflammatory cells (haemotoxylin and eosin stain; $\times 410$; bar $=16 \mu \mathrm{m}$ ). (C) Normal perimysium (haemotoxylin and eosin stain; $\times 230 ;$ bar $=28 \mu M)$; (D) High power view of normal perimysium $(\times 460$; bar $=14 \mu M) ;(E)$ Perimysial connective tissue in a muscle biopsy from a patient with anti-fo-1 antibodies stains diffusely for alkaline phosphatase $(\times 200 ;$ bar $=32 \mu m)$; (F) Perimysial connective tissue in a normal muscle biopsy shows no staining for alkaline phosphatase $(\times 200 ;$ bar $=32 \mu \mathrm{m})$.

clinical+pathology series (table 2). The pathology and prospective clinical+pathology series are considered together here, but separately in table 2 .

\section{DERMATOMYOSITIS}

The 26 dermatomyositis biopsies all showed, by definition, a perifascicular distribution of atrophic, and in most cases myopathic, muscle fibres (table 2). Perifascicular myopathic changes were also found in anti-Jo-1 biopsies. In several other respects the pathology in the anti-Jo-1 biopsies differed from dermatomyositis. Features found less commonly in dermatomyositis than in patients with antiJo- 1 antibodies included perimysial connective tissue fragmentation and rarefaction (12\%; three of $26 ; p<0.001)$ and selective perimysial cellular inflammation (31; eight of 26 ; $\mathrm{p}<0.001)$. Features found more commonly in dermatomyositis than in patients with antiJo-1 antibodies were accumulations of inflammatory cells selectively around vessels (62\%; 16 of $26 ; \mathrm{p}=0.004)$, alkaline phosphatase staining of small vessels $(58 \% ; 15$ of 26 ; $\mathrm{p}=0.01$ ), and cytochrome oxidase negative muscle fibres $(62 \% ; 16$ of $26 ; \mathrm{p}<0.001)$, usually in a perifascicular distribution. The mean capillary index, 0.55 (SD 0.08), was reduced $(\mathrm{p}<0.05)$ in dermatomyositis (fig 4) compared with anti-Jo-1 and other inflammatory myopathies, and control muscles.

POLYMYOSITIS

Muscle biopsies supportive of a diagnosis of polymyositis (27 patients) showed even more differences from the anti-Jo-1 pathology. By definition, there was no selective perifascicular 

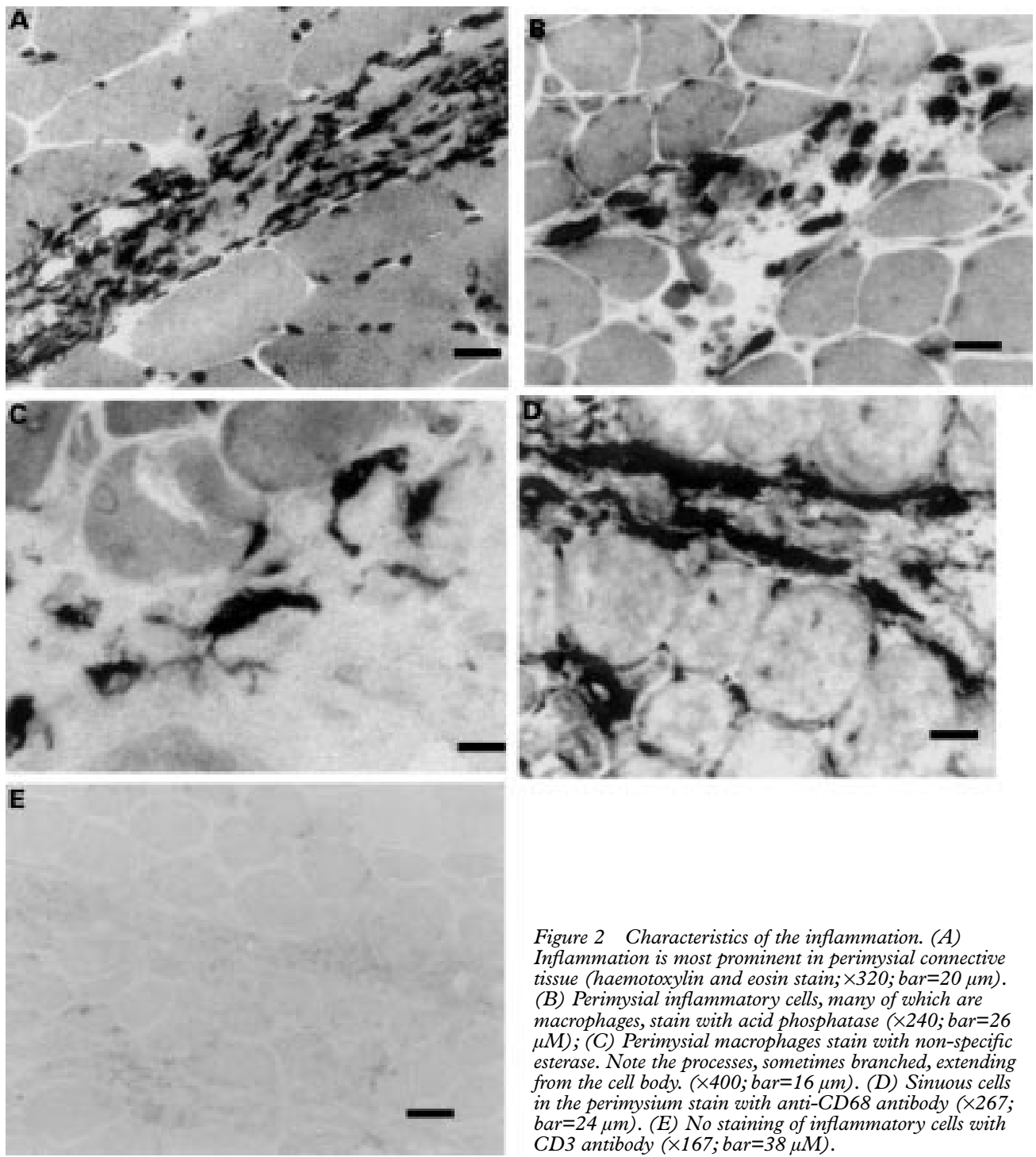

Figure 2 Characteristics of the inflammation. (A) Inflammation is most prominent in perimysial connective tissue (haemotoxylin and eosin stain; $\times 320$; bar $=20 \mu \mathrm{m}$ ). (B) Perimysial inflammatory cells, many of which are macrophages, stain with acid phosphatase $(\times 240$; bar $=26$ $\mu M) ;(C)$ Perimysial macrophages stain with non esterase. Note the processes, sometimes branched, extending from the cell body. $(\times 400 ;$ bar $=16 \mu \mathrm{m})$. (D) Sinuous cells in the perimysium stain with anti-CD68 antibody $(\times 267$; bar $=24 \mu \mathrm{m})$. (E) No staining of inflammatory cells with CD3 antibody $(\times 167 ;$ bar $=38 \mu \mathrm{M})$.

distribution of pathology in polymyositis $(0 \%$; 0 of 27; p<0.001 $v$ anti-Jo-1 pathology). Inflammation was commonly focused around vessels $(67 \% ; 18$ of $27 ; \mathrm{p}=0.003)$ and in the endomysium $(70 \% ; 19$ of $27 ; \mathrm{p}=0.005)$, but only occasionally diffusely in the perimysium $(22 \%$; six of $27 ; \mathrm{p}<0.001)$. In the perimysium, connective tissue fragmentation and rarefaction $(15 \%$; four of $27 ; \mathrm{p}<0.001)$ and alkaline phosphatase staining $(41 \% ; 11$ of $27 ; \mathrm{p}=0.01)$ were less common in polymyositis than in the anti-Jo-1 group. An excess ( $>3 \%$ ) of cytochrome oxidase negative muscle fibres, distributed in a scattered pattern through the muscle, was found in $33 \%$ (nine of $27 ; \mathrm{p}=0.04$ ). All nine of the patients with polymyositis and scattered cytochrome oxidase negative muscle fibres had a clinical syndrome of selective quadriceps weakness early in their disease course, as previously described. ${ }^{8}$ The mean capillary index in Jo-1 negative polymyositis muscles, 0.95 (SD 0.10), was similar to that in controls.

OTHER INFLAMMATORY DISORDERS

Muscle biopsies from patients with inclusion body myositis had, by definition, frequent

focal cellular invasion of muscle fibres and endomysial inflammation (100\%; eight of eight; $\mathrm{p}<0.001 v$ anti-Jo-1 pathology), and rimmed vacuoles. Perimysial inflammation and connective tissue fragmentation, and perifascicular muscle fibre atrophy, did not occur $(p<0.001)$. Patients with fasciitis were the only control group that commonly had selective perimysial inflammation ( $100 \%$; five of five)

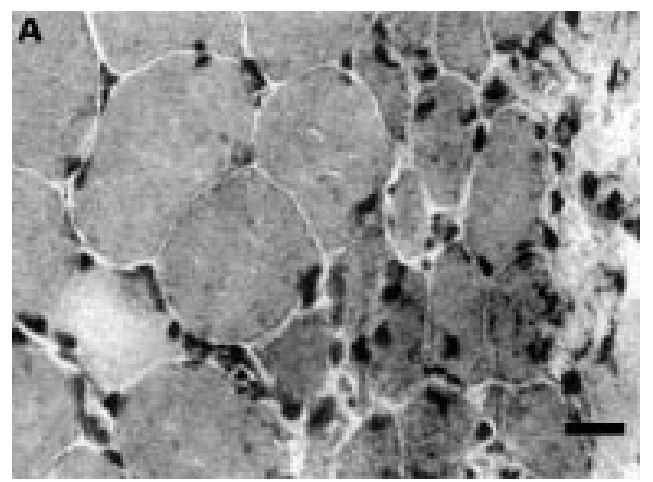

Figure 3 Perifascicular myopathy: muscle fibres at the edge of the fascicle, near the perimysium, are small (haemotoxylin and eosin stain; $\times 300 ;$ bar $=21 \mu \mathrm{M}$ ). 

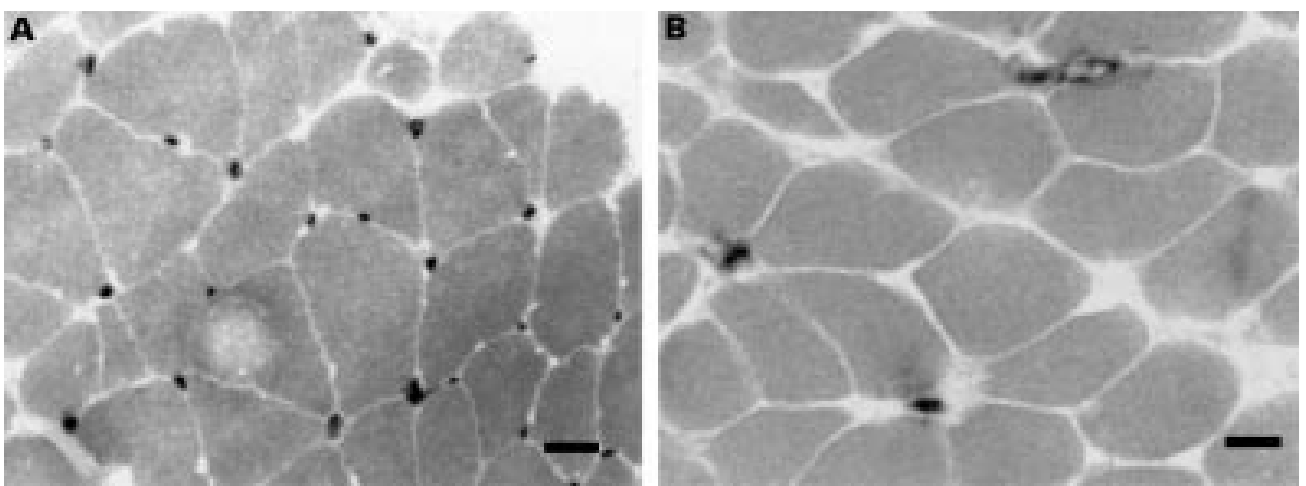

Figure 4 Capillaries in muscle visualised by Ulex europaeus agglutinin I lectin staining. (A) Normal density of dark staining capillaries (capillary index) in an anti-fo-1 muscle biopsy. Note that all muscle fibres have at least one neighbouring capillary $(\times 240 ;$ bar $=26 \mu \mathrm{m}) ;(B)$ Reduced density of dark staining capillaries (capillary index) in a patient with dermatomyositis. Note that most muscle fibres have no neighbouring capillary ( $\times 240 ;$ bar=26 $\mu \mathrm{m})$.

and connective tissue fragmentation (60\%; three of five) in a pattern similar to anti-Jo-1 myositis. However, by contrast with patients with anti-Jo-1 antibodies, muscle fibre pathology was uncommon $(20 \%$; one of five; $p<0.01)$ in the fasciitis group. The mean capillary index in fasciits muscles, 0.88 (SD 0.13), was similar to that of controls.

\section{Discussion}

The Jo-1 antigen, histidyl-t-RNA synthetase, is a cytoplasmic protein that is usually located in a speckled pattern on ANA testing using HEp-2 cells. ${ }^{31-16}$ Anti-Jo-1 antibodies are associated with clinical syndromes that most commonly present in the spring, and variably include weakness with an inflammatory myopathy, interstitial lung disease, skin changes (mechanic's hands, Raynaud's phenomena), non-erosive seronegative arthritis of the hands, and fever. ${ }^{4}{ }^{517-21}$ Muscle weakness may respond to imunosuppressive therapy, but there is a high mortality related to the systemic involvement. ${ }^{22-25}$ Our patients with serum antiJo- 1 antibodies all had some of the typical features of this syndrome (table 1). Signs of skeletal muscle involvement (proximal weakness and myalgias) were especially common due to our method of selecting cases for analysis. Weakness often improved after treatment with corticosteroids, but two of our 11 patients died within 2 years of disease onset, consistent with reports of a poor prognosis for many with this syndrome. ${ }^{4}$ Compared with classic polymyositis or dermatomyositis, one distinguishing feature in two patients was the nature of the skin lesions, which were hyperkeratotic, fissuring, and hyperpigmented (mechanic's hands), rather than the relatively flat, scaling erythematous rash in typical dermatomyositis. A second distinguishing feature in two patients was prominent interstitial lung disease, a syndrome not commonly associated with other inflammatory myopathies. In most of our patients, however, the clinical features, with myalgias and proximal weakness, and electrophysiological features, irritable myopathy, of the patients with anti-Jo-1 antibody associated myositis (table 1), were similar to typical polymyositis.

Two different pathological patterns are generally described in the inflammatory myopathies (table 3 ). In polymyositis and inclusion body myositis syndromes endomysial mononuclear cell infiltration and focal invasion of muscle fibres are common, ${ }^{26}{ }^{27}$ and were found in our patients (tables 2 and 3). Additional pathological features in some patients with myositis, such as cytochrome oxidase negative muscle fibres ${ }^{8}$ or inclusion bodies ${ }^{27}$ probably define subgroups of inflammatory myopathy. In dermatomyositis the most distinctive pathological change is perifascicular localisation of muscle fibre pathology. ${ }^{27}{ }^{28}$ This abnormality is generally ascribed to an immune attack on muscle microvasculature with resulting muscle ischaemia. ${ }^{27}{ }^{28}$ The perifascicular myopathic muscle fibres with reduced or absent cytochrome oxidase activity in dermatomyositis (table 2) probably result from this ischaemia. Perivascular inflammation may be especially apparent when immune myopathies occur in the setting of a systemic connective tissue disease. ${ }^{29}$ Inflammation around moderate sized vessels was found in most of our patients with dermatomyositis, polymyositis, and inflammatory myopathies with negative anti-Jo-1 serology (table 2).

The muscle biopsy findings in patients with anti-Jo-1 antibodies differed from pathological patterns in dermatomyositis, polymyositis, and inclusion body myositis (tables 2 and 3 ). One prominent and distinctive feature of anti-Jo-1 biopsies ( $p<0.001 v$ other groups) was the high frequency of macrophage predominant inflammation in, and fragmentation of, perimysial connective tissue (figs 1 and 2). The fragmentation was manifest as multifocal pale staining and rarefaction of perimysial connective tissue on haematoxylin and eosin, modified Gomori trichrome, and Verhof van Giesson stains. Focal small loculations and frequent large nucleated cells (macrophages) differentiated the pathological fragmentation from the preparation artifact that can be seen in perimysium when a muscle biopsy is pulled apart during preparation. Further evidence of connective tissue pathology in patients with anti-Jo-1 antibodies was the frequent (91\%) alkaline phosphatase staining of the perimysium (fig $1 \mathrm{E}$ ). Another notable feature of anti-Jo-1 biopsies was the paucity of vascular pathology. Capillary density (index) was normal, by contrast with the reduction found in dermatomyositis (fig 4). 
Alkaline phosphatase staining of small vessels was also less common $(p=0.004)$ in patients with anti-Jo-1 antibodies(9\%) compared with dermatomyositis (58\%). Perivascular inflammation was found in only $13 \%$ of anti-Jo-1 biopsies compared with $68 \%$ in other inflammatory myopathies $(p<0.001)$. None of the eight anti-Jo-1 biopsies studied had evidence of membrane attack complex deposition on microvasculature (data not shown). As in dermatomyositis, muscle fibre pathology, such as atrophy, degeneration and regeneration, was usually most abundant in regions near perimysial connective tissue. However, myopathic muscle fibres in perifascicular regions of anti-Jo-1 biopsies usually had normal cytochrome oxidase staining compared with most $(62 \%)$ dermatomyositis biopsies having fibres with abnormal cytochrome oxidase staining $(\mathrm{p}<0.001)$.

The pathology in perimysial connective tissue in patients with anti-Jo-1 antibodies was similar to that seen with fasciitis in this series, and in previous reports. ${ }^{30}{ }^{31}$ However, anti-Jo-1 syndromes differ from most of the previously described inflammatory disorders involving muscle fascia. Eosinophilic fasciitis is characterised by eosinophilia, and painful swelling and induration of the skin. ${ }^{14}$ In systemic sclerosis there is marked thickening of the skin and a pattern of ANA results that differs from that usually found in patients with anti-Jo-1 antibodies. ${ }^{30} \mathrm{~A}$ pathological contrast to antiJo-1 syndromes was that biopsies from our patients with fasciitis usually had little muscle fibre pathology. Fascial pathology without myopathy might also be found in muscle from patients with anti-Jo-1 antibody syndromes that are not associated with weakness. ${ }^{5}$ No such patients were included in our pathology series.

We conclude that the muscle pathology in anti-Jo- 1 antibody associated myositis includes prominent involvement of perimysial connective tissue. This change is commonly accompanied by variable degrees of atrophy, regeneration, or necrosis of neighbouring perifascicular muscle fibres. Our data suggest that anti-Jo-1 associated myositis is an immune syndrome with pathological, as well as clinical, ${ }^{4132}$ distinctions from the classically described changes in other major classes of inflammatory myopathy, including dermatomyositis, polymyositis, and inclusion body myositis. Systemic involvement of connective tissue with antigenic similarities to perimysium could explain the coexistence of muscular, interstitial lung, joint, and skin disorders in many patients with anti-Jo-1 syndromes. The finding of prominent perimysial connective tissue involvement in patients with acquired inflammatory myopathy syndromes should prompt a search for serum antisynthetase antibodies, and careful monitoring of pulmonary function and chest imaging, as lung involvement is one of the features that contributes to the high morbidity of the anti-Jo-1 syndrome.

Kathleen Doster collected clinical data on several patients. James Planer and Jin Yue performed muscle histochemistry and James Planer and Jin Yue
1 Targoff IN. Autoantibodies to aminoacyl-transfer RNA synthetases for isoleucine and glycine. Two additional synthetases are antigenic in myositis. 7 Immunol

2 von Muhlen C, Tan EM. Autoantibodies in the diagnosis of systemic rheumatic diseases. Semin Arthritis Rheum 1995; 24:323-58

3 Mathews MB, Bernstein RM. Myositis autoantibody inhibits histidyl-tRNA synthetase: a model for autoimmunity. Nature 1983;304:177-9.

4 Arnett FC, Hirsch TJ, Bias WB, et al. The Jo-1 antibody system in myositis: relationships to clinical features and HLA. F Rheumatol 1981;8:925-30.

5 Friedman AW, Targoff IN, Arnett FC. Interstitial lung disease with autoantibodies against aminoacyl-tRNA synthetases in the absence of clinically apparent myositis. Semin Arthritis Rheum 1996;26:459-67.

6 Griggs RC, Askanas V, DiMauro S, et al. Inclusion body Griggs RC, Askanas V, DiMauro S, et al. Inclusion bod
myositis and myopathies. Ann Neurol 1995;38:705-13.

7 Bohan A, Peter JB, Bowman RL, et al. A computer-assisted analysis of 153 patients with polymyositis and dermatomyanalysis of 153 patients with polymyositis an
ositis. Medicine (Baltimore) 1977;56:255-86.

8 Blume G, Pestronk A, Frank B, et al. Polymyositis with cytochrome oxidase negative muscle fibres. Early quadriceps weakness and poor response to immunosuppressive therapy. Brain 1997;120:39-45.

9 Dubowitz. Muscle biopsy, a practical approach. London: Ballière Tindall, 1985:19-40.

10 Arahata K, Engel AG. Monoclonal antibody analysis of mononuclear cells in myopathies: IV. Cell-mediated toxicity and muscle fiber necrosis. Ann Neurol 1988;23. 168-73.

11 Emslie-Smith A, Engel AG. Microvascular changes in early and advanced dermatomyositis: a quantitative study. Ann Neurol 1990;27:343-56.

12 Targoff IN, Reichlin M. Measurement of antibody to Jo-1 by ELISA and comparison to enzyme inhibitory activity. $\mathcal{F}$ Immunol $1987 ; \mathbf{1 3 8}: 2874-82$.

13 Nishikai M, Reichlin M. Heterogeneity of precipitating antibodies in polymyositis and dermatomyositis. Characterization of the Jo-1 antibody system. Arthritis Rheum 1980;23:881-8

14 Yoshida S, Akizuki M, Mimori T, et al. The precipitating antibody to an acidic nuclear protein antigen, the Jo-1, in connective tissue diseases. A marker for a subset of polymyositis with interstitial pulmonary fibrosis. Arthritis Rheum 1983;26:604-11.

15 Yang DC, Dang CV, Arnett FC. Rat liver histidyl-tRNA synthetase. Purification and inhibition by the myositisspecific anti-Jo-1 autoantibody. Biochem Biophys Res Commun 1984;120:15-21.

16 Shi MH, Tsui FW, Rubin LA. Cellular localization of the target structures recognized by the anti-Jo-1 antibody:
immunofluorescence studies on cultured human myoblasts. F Rheumatol 1991;18:252-8.

17 Bernstein RM, Morgan SH, Chapman J, et al. Anti-Jo-1 antibody: a marker for myositis with interstitial lung disease. BMF 1984;289:151-2.

18 Cohen MG, Ho KK, Webb J. Finger joint calcinosis followed by osteolysis in a patient with multisystem connective tissue disease and anti-Jo-1 antibody. $\mathcal{F}$ Rheumatol 1987;14:605-8.

19 Oddis CV, Medsger TAJ, Cooperstein LA. A subluxing arthropathy associated with the anti-Jo-1 antibody in polymyositis/dermatomyositis. Arthritis Rheum 1990;33: 1640-5.

20 Mitra D, Lovell CL, Macleod TI, et al. Clinical and histological features of mechanic's hands in a patient with antibodies to Jo-1-a case report. Clin Exp Dermatol 1994;19:146-8.

21 Targoff IN. Immune manifestations of inflammatory muscle disease. Rheum Dis Clin North Am 1994;20:857-80.

22 Rider LG, Miller FW, Targoff IN, et al. A broadened spectrum of juvenile myositis. Myositis-specific autoantibodies in children. Arthritis Rheum 1994;37:1534-8.

23 al-Janadi M, Smith CD, Karsh J. Cyclophosphamide treatment of interstitial pulmonary fibrosis in polymyositis/ dermatomyositis. F Rheumatol 1989;16:1592-6.

24 Jenkins EA, Hull RG, Thomas AL. D-penicillamine and polymyositis: the significance of the anti-Jo-1 antibody. $\mathrm{BrF}$ Rheumatol 1993;32:1109-10.

25 Dawson JK, Abernethy VE, Lynch MP. Effective treatment of anti Jo-1 antibody-positive polymyositis with cyclosporin. Br f Rheumatol 1997;36:144-5.

26 Engel AG, Arahata K, Emslie-Smith A. Immune effector Engel AG, Arahata K, Emslie-Smith A. Immune effector
mechanisms in inflammatory myopathies. Res Publ Assoc Rechanisms in inflammatory myop

27 Dalakas MC. Polymyositis, dermatomyositis and inclusionbody myositis. N Engl F Med 1991;325:1487-98.

28 Kissel JT, Mendell JR, Rammohan KW. Microvascular deposition of complement membrane attack complex in dermatomyositis. N Engl F Med 1986;314:329-34.

29 Ringel SP, Carry MR, Aguilera AJ, Starcevich JM. Quantitative histopathology of the inflammatory myopathies. Arch Neurol 1986;43:1004-9.

30 Ringel SP, Forstot JZ, Tan EM, et al. Sjögren's syndrome and polymyositis or dermatomyositis. Arch Neurol 1982;39: 157-63.

31 Simon DB, Ringel SP, Sufit RL. Clinical spectrum of fascial inflammation. Muscle Nerve 1982;5:525-37.

32 Love LA, Leff RL, Fraser DD, et al. A new approach to the classification of idiopathic inflammatory myopathy: myositis-specific autoantibodies define useful homogeneous patient groups. Medicine (Baltimore) 1991;70:360-74. 